THE

IJOURNAL
DePace, M. (2019). The ijournal 5, I, 98-

106. 10.33 I37/ijournal.v5il.3346 |

\title{
Fidesz and the Re-inscription of Budapest's Infrastructure
}

\author{
Madelaina DePace
}

\section{Abstract}

First elected in 1998, Hungary's current leading political party, Fidesz, has used its influence to dismantle the left-wing democratic narrative constructed by the municipal body of the city by inscribing its own ideals on the city's infrastructure. Through parks, memorials, and museums, the national identity of Budapest has been reshaped by those in power. This paper explores the ways in which political power and ideology are reflected in city infrastructure and how that infrastructure, in turn, is used to support political power and ideology. Using Budapest as a case study highlights the ways in which social memory can be manipulated to the benefit or detriment of democratic society.

Keywords: National Memory, National Identity, City Infrastructure, Hungary, Budapest, Democratic Narrative 
The Millennial celebration was not just an occasion for revelry; it was an historic opportunity for the Hungarian government to construct an integrated nation and historical ideology depicting the de facto imperfect state as de jure a whole, inspiring a sense of continuity, of permanent and unshakeable stability, while at the same time presenting the status quo as inevitable (Gerö in Barenscott, 2010, p. 572).

The above quote by historian András Gerő reflects on the nature of the Millennial celebrations in Budapest in 1896. As having recently been granted equal political status with Austria and as the fastest-growing city in Europe at the end of the nineteenth century (Barenscott, 2010), those in power in Hungary wished to reflect their nation's status in the infrastructure of their capital city. However, this observation could have just as easily been made upon examining the events that occurred at the turn of the twentieth century following the collapse of Communism and the rise to power of Fidesz, Hungary's current leading political party. Elected for the first time in 1998, Fidesz immediately set about dismantling the left-wing democratic narrative constructed by the municipal body of the city by inscribing its own ideals onto the city's infrastructure (Palonen, 2013). These endeavours by Fidesz have continued to this day. Thus, it may be argued that Fidesz is reverting Budapest's infrastructure back to that of the late nineteenth century, a time they consider to be Hungary's golden age. Fidesz and Prime Minister Viktor Orbán are attempting to re-inscribe Hungary's national identity of the past onto the present and erase the memory of the majority of the twentieth century. The construction of the House of Terror Museum physically writes Fidesz' beliefs on the city streets, the creation of Millennial Park aims to bring Budapest's urban centre into the rural, and the removal of the Nagy memorial statue erases an iconic moment from the country's past and replaces it with a moment significant to Orbán.

Infrastructure is inherent to the function of a city; how the streets are arranged, where and how public transportation runs, and the location and style of public buildings and memorial sites all contribute to this infrastructure. As Geoffrey Bowker and Susan Leigh Star describe in their work Sorting Things Out (1999), all of these elements work together to help the user (i.e. city dweller) navigate both physically and intellectually through the system it is meant to support (i.e. the city itself). Intellectual navigation of a city is especially significant as the layout of buildings and streets contribute to the construction of social memory. However, Bowker and Stars' work also relates that large and complex infrastructures cannot be changed from above, and that compromise and discussion is required to address changes that need to be made (Bowker and Star, 1999). 
Yet, infrastructural changes that reflect current events can also recreate society's knowledge of the past (Bowker and Star, 1999). This was the aim of the Hungarian government following the Ausgleich in 1867, an agreement in which Hungary was granted equal political power with Austria. The years leading up to 1896 (the Millennial anniversary of the Hungarian people entering the Carpathian basin) saw an explosion of building projects to modernize Budapest's infrastructure, create buildings worthy of a great European city, and showcase their own unique cultural identity (Barenscott, 2010; also see Enyedi and Szirmai, 1992).

Fidesz has been aiming to do the same thing since their accession to power twenty years ago. Similar to the government at the close of the nineteenth century, Fidesz has been attempting to tie Hungary's present more firmly to the past. However, unlike leaders of the nineteenth century, they have been trying to link their present in a direct line to this past by erasing the majority of the twentieth century (Palonen, 2013). As discussed below, in negating both Hungary's role during the Second World War and the entire Communist regime that followed, Fidesz wishes to bring current Hungary closer to what they see as the "golden" past. They are therefore attempting to change the infrastructure from above without the discussion and nuance that Star and Rohleder call for in Bowker and Star (1999), and in doing so are molding social memory to fit their own ideals.

The House of Terror Museum opened in 2002 as part of Prime Minister Orbán’s reelection campaign and is housed in what used to be the Arrow Cross Headquarters (Hungary's fascist party of the 1930s and 1940s), and later also the Communist Secret Police headquarters (Turai, 2009). This building lies along the UNESCO World Heritage Protected area of Andrássy Boulevard, and thus cannot be significantly altered, something Fidesz was able to circumvent by installing an overlay to separate this building from the others surrounding it. This black installation has the word "TERROR" carved out of it, written in negative space to literally inscribe its presence on the sidewalk around the museum on bright days (Figure 1). Though the museum is billed as a space where the victims of the fascist and communist regimes are memorialized, many argue that it rather serves to disassociate Hungary's culpability with said regimes (Rév, 2005). The use of language within the museum creates a link between the Arrow Cross and Communist parties and suggests that the members of these parties weren't really Hungarians, but rather that Hungary was the victim of foreign terrorist regimes (Rév, 2005). The museum thereby erases this period of history (1944-1989) from the narrative of Hungarian identity: since these years saw Hungary under the thumb of these "foreign" terrors, they are not a part of Hungary's past. 


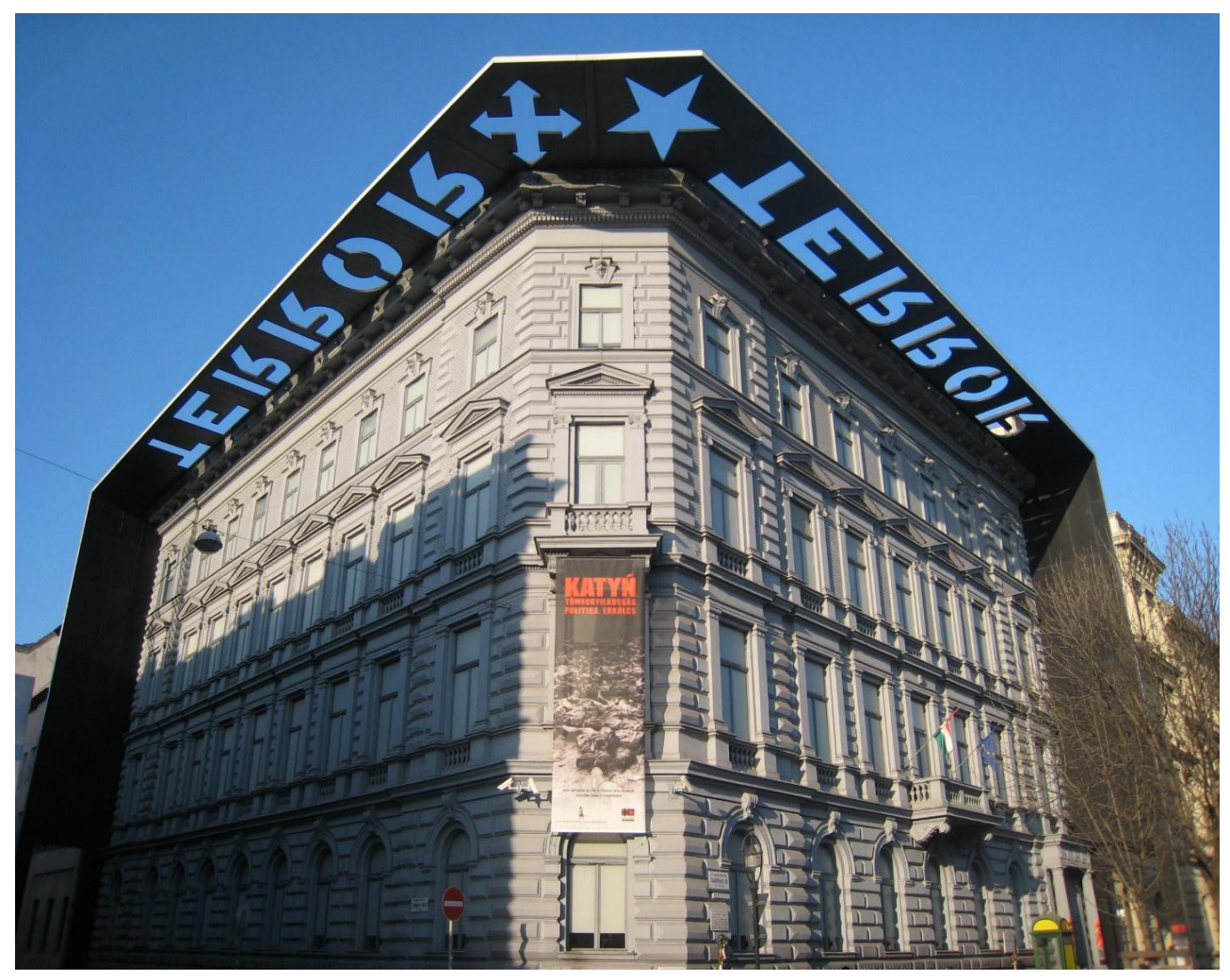

Figure 1: Terror Museum Facade. From House of Terror, by Tbachner, 2009, Wikipedia. https://en.wikipedia.org/wiki/House_of_Terror. Copyright CC-BY 3.0

The UNESCO-protected street on which the House of Terror museum lies was largely built up at the end of the nineteenth century (Vörös, 1997), and so the presence of the House of Terror there only serves to tie Fidesz's present with that golden nineteenth century. The ideology presented within the museum is therefore linked by the infrastructure of Andrássy Boulevard to the other great nineteenth century buildings that similarly lie along this street; the opera house, the Millennial monument, and the subway that runs beneath Andrássy are all reminders of the time when the idea of a specifically Hungarian national identity shaped the construction of Budapest's urban infrastructure (Nemes, 2005). Thus, while the ideology presented within the House of Terror Museum bypasses the majority of the twentieth century, Fidesz is able to link the building with nineteenth-century national identity, thereby marrying their present to that past.

While the Museum is linked ideologically to its surroundings, the black frame around the building also serves to separate it from its surroundings. In her article concerning the Hudson Yards in New York City, Shannon Mattern (2019) discusses how circuits and data flows will be overlaid across the existing topology of the city, altering the infrastructure of the Hudson Yards to shape the area in the image that the urban designers hope to achieve. The added element on the House of Terror's facade aims to do something similar: it acts as a literal frame to separate 
the museum from the buildings around it. It is therefore overlaying "TERROR" on to Budapest's topology and in this way wrests control of some of the city's infrastructure away from the municipality. As Palonen mentions, the municipality of Budapest was liberal and more left-wing than Fidesz (2013). Rather than initiating a dialogue with their opposition, Fidesz began to shift the identity of the city away from the left through the architecture of the House of Terror, using the "TERROR" overlay as a physical representation of their version of Hungarian identity (Palonen, 2013).

Millennial Park, on the other hand, while also demarcated from the rest of the city, suggests a link to rural Hungary as a point of opposition from Budapest's urban centre. Located beside Széll Kálmán Square - one of the busiest transportation hubs in the city - the park, conceived of by Fidesz in 2001, provides an escape from the fast-paced metropolis represented at Széll Kálmán (Palonen, 2013). This creates a parallel to nineteenth-century Budapest which despite rapid expansion did not reach today's urban boundaries. Indeed, it is easy in a designated park space to invoke the rural atmosphere that was present on the outskirts of Budapest in the late nineteenth century. Moreover, the appellation Millennial Park provides an additional link to the Millennial celebrations of 1896 . Even the street running parallel to the park is named Millennial Park, placing that link within the minds of those passing by the park. As stated above, the Budapest of 1896 did not reach the expanse of modern Budapest, so not only does Millennial Park evoke the rural within the urban as a reminder of the nineteenth-century city, but as Fidesz' main centres of support are rural, the park also symbolically brings Budapest into that realm (Palonen, 2013).

Furthermore, in 2001 an exhibition titled "Dreamers of dreams, Hungarians writing the world" opened in the park, showcasing famous Hungarians from various arts and science disciplines (Palonen, 2013). Similar to the 1896 World's Fair, this exhibit was meant to showcase Hungary's artistic and technological achievements, demonstrating that Hungary deserves its place on the world stage (see Barenscott, 2010). The Fidesz-sponsored exhibit in 2001 therefore picks up that memory of Hungary as a great cultural power and strengthens the bond between events in 1896 and the end of the twentieth century, suggesting that Fidesz' governance is the natural succession to the leaders during those millennial celebrations.

Fidesz' efforts to minimize Hungary's culpability in the major events of the mid-to-late twentieth century has culminated in their most recent action of removing the memorial statue of Imre Nagy. Nagy (1896-1958) was prime minister of Hungary during the 1956 Revolution, during which he supported the reform aims of the revolutionaries and was hanged in 1958 
for doing so (Benziger, 2002). As such, he has been revered as a martyr for freedom by the Hungarian people, and a statue in his memory was erected in Martyr's Square in 1996 depicting Nagy standing on a bridge looking towards the parliament building ("Hungary removes statue of anti-Soviet hero Imre Nagy," 2018) (Figure 2). In late December of 2018, sometime before dawn, the statue was removed with the alleged intention of relocating it to the more remote Jaszai Mari Square, though this has yet to be done (Novak, 2018).

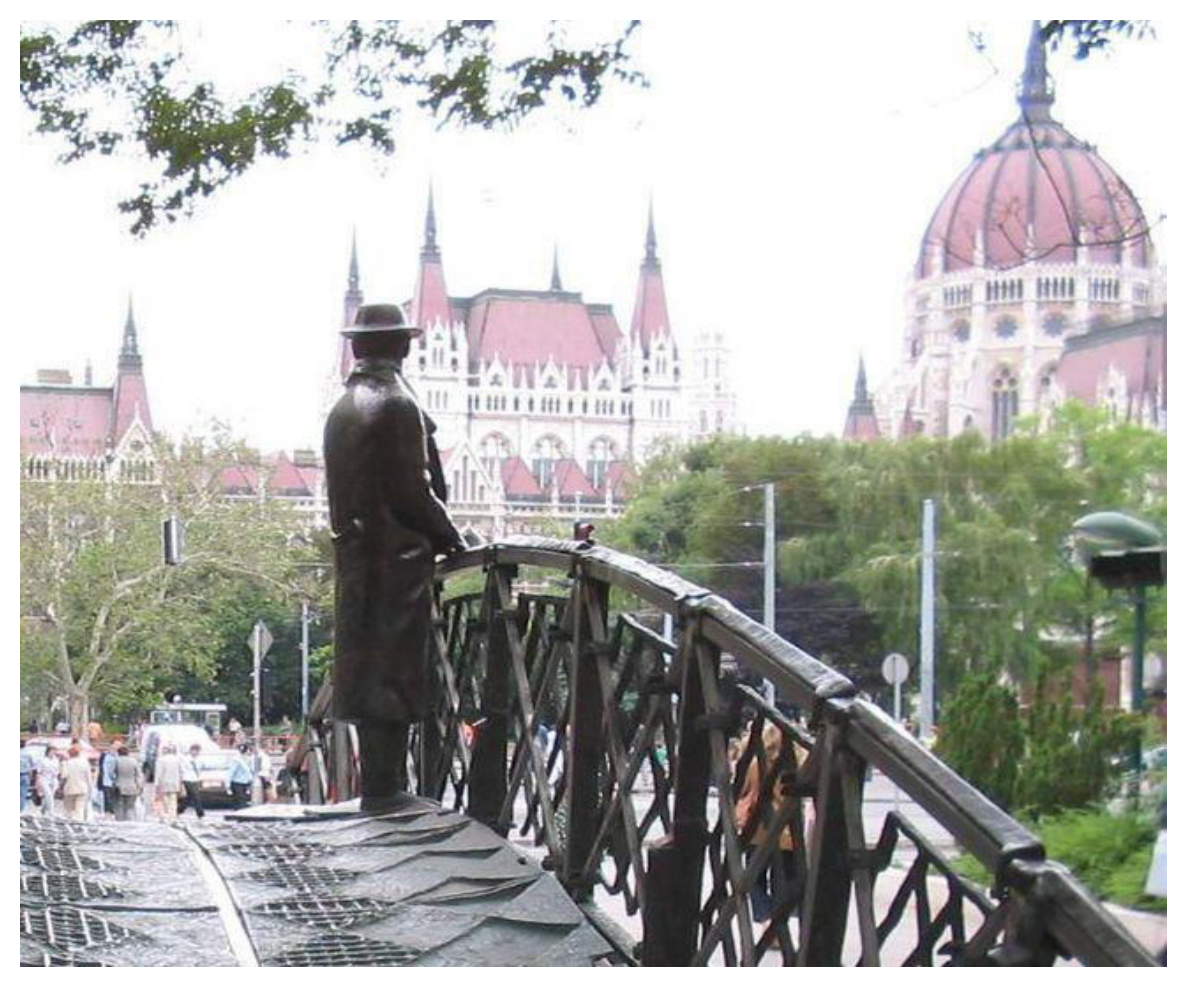

Figure 2: Imre Nagy Memorial Statue. From Imre Nagy, facing Parliment, by Adam78, 2004, Wikimedia Commons. https://commons.wikimedia.org/wiki/File:Imre_Nagy,_ Budapest,_facing_Parliament.jpg.

After the collapse of communism in 1989, Nagy was disinterred from his anonymous grave and reburied with a ceremony attended by 100,000 people, giving vindication to the martyr status of his figure (Verdery, 1999). However, as Fidesz has shifted more and more to the right, vindication of the freedom fighter as evoked by Nagy is no longer desirable. Indeed, Fidesz has stated its aim is to return Budapest to the way it was prior to the Second World War, when the country was led by regent Admiral Miklós Horthy (Novak, 2018).

Horthy remains a controversial figure in Hungary owing to his alliance with the Third Reich (Fenyo, 1972; also see Sakmyster, 1994). During his rule, Martyr's Square housed a memorial to the victims of the brief 1919 communist regime under Béla Kun, which Fidesz has announced will be replacing the Nagy memorial ("Hungary removes statue of anti-Soviet hero Imre Nagy," 2018). This action once again highlights Fidesz' overt demonization of all 
communist regimes in Hungary, as well as Fidesz' negation of major twentieth century events. Removing Nagy's statue negates not only the events of the 1956 Revolution but also Nagy's rehabilitation in 1989. No longer part of the city's infrastructure, these events will therefore be removed from the minds of those who traverse the space, which serves to bring Hungary's present closer to that of Fidesz' ideal past. Though in this instance Fidesz wishes to revert the square to its appearance from Horthy's rule, tying the infrastructure of the square to Horthy equally brings to mind the Habsburg era, when Horthy acted as aide-de-camp for Emperor Franz Joseph (Rutter, n.d.).

In his discussion concerning style versus design thinking, Cameron Tonkinwise states that "design is about changing situations into preferable ones" (2011, p. 535). In the case of Fidesz, preferable situations involve shifting the social memory inherent in Budapest's infrastructure to recall those moments that they perceive to be the most important. As students of information, it is important to recognize these undemocratic movements from this type of authority. This is especially true as we become professionals whose job it is to maintain and facilitate access to memory. We, as archivists or librarians, should track these changes so that a record may be captured of what happened, when, and why, so that any narrative coming from above may be countered with a societal narrative pushing back from below.

By removing the Nagy memorial, Fidesz is designing Martyr's square into the way it used to be when authoritarianism was acceptable - either in the form of Horthy's regency or the Imperial rule of the late nineteenth century. Similarly, by building a green space and naming it Millennial Park, Fidesz has symbolically imposed its centre of rural support into Budapest's infrastructure while also recalling the nature of the nineteenth-century city. The House of Terror Museum likewise serves to impose Fidesz' ideology onto the historic Andrássy Boulevard, integrating itself onto the street while simultaneously maintaining distinction via its black border around the building. Fidesz, bent on rewriting Hungary's past by equating communism and fascism as a foreign enemy and thereby negating the majority of the twentieth century, is reverting Budapest's infrastructure to that of their idea of the golden age of the city. By establishing the House of Terror, building Millennial Park, and removing Nagy's memorial, they are re-inscribing their own ideals of Budapest's golden nineteenth century onto the present infrastructure of the city. 


\section{References}

(2018, December 28). Hungary Removes Statue of Anti-Soviet Hero Imre Nagy. BBC News. Retrieved from https://www.bbc.com/news/world-europe-46704111.

Barenscott, D. (2010). Articulating Identity through the Technological Rearticulation of Space: The Hungarian Millennial Exhibition as World's Fair and the Disordering of Fin-de-Siècle Budapest. Slavic Review, 69(3), 571-590.

Benziger, K. P. (2002). Imre Nagy, Martyr of the Nation: Contested Memory and Social Cohesion. East European Quarterly, 36(2), 171-190.

Bowker, G. C., \& Star, S. L. (1999). Sorting Things Out: Classification and its Consequences. Cambridge: MIT Press.

Budapest Haus des Terrors [Digital Image]. (2009). Retrieved from https://en.wikipedia.org/ wiki/House of Terror.

Enyedi, G., and Szirmai, V. (1992) Budapest: A Central European Capital. (V. Gáthy \& C. Hebbert, Trans.). London: Belhaven Press.

Fenyo, M. D. (1972). Hitler, Horthy, and Hungary: German-Hungarian Relations, 1941-1944. New Haven: Yale University Press.

Imre Nagy, Budapest, facing Parliament [Digital Image]. (2004). Retrieved from https:// commons.wikimedia.org/wiki/File:Imre_Nagy,_Budapest,_facing_Parliament.jpg

Mattern, S. (2019, April). Instrumental City: The View from Hudson Yards circa 2019. Places Journal. Retrieved from https://placesjournal.org/article/instrumental-city-new-yorkhudson-yards/.

Nemes, R. (2005). The Once and Future Budapest. DeKalb: Northern Illinois University Press.

Novak, B. (2018, December 28). Hungarians Fume as Statue of Former Leader is Downgraded. The New York Times. Retrieved from https://www.nytimes.com/2018/12/28/world/ europe/hungary-statue-nagy.html. 
Oltay, E. (2012). Fidesz and the Reinvention of the Hungarian Centre-Right. Budapest: Századvég Kiadó.

Palonen, E. (2013). Millennial Politics of Architecture: Myths and Nationhood in Budapest. Nationalities Papers, 41(4), 536-551.

Rév, I. (2005). Retroactive Justice: Prehistory of Post-Communism. Stanford: Stanford University Press.

Rutter, O. (n.d.) Regent of Hungary: The Authorized Life of Admiral Horthy. London: Rich and Cowan Ltd.

Sakmyster, T. (1994). Hungary’s Admiral on Horseback: Miklós Horthy, 1918-1944. New York: Columbia University Press.

Tonkinwise, C. (2011). A Taste for Practices: Unrepressing Style in Design Thinking. Design Studies, 32, 533-545.

Turai, H. (2009). Past Unmastered: Hot and Cold Memory in Hungary. Third Text, 23(1), 97106.

Verdery, K. (1999). The Political Lives of Dead Bodies: Reburial and Postsocialist Change. New York: Columbia University Press.

Vörös, K. (1997). Birth of Budapest: Building a Metropolis, 1873-1918. In A. Gerő \& J. Poór (Eds.), Budapest: A History from its Beginnings to 1998 (pp. 103-138). (J. Zinner, C. D. Eby, \& N. Arató, Trans.). New York: Columbia University Press. 